\title{
Evaluating Brand Relationship Quality through Social Media Interaction
}

\author{
Zaibunnisa, Saima Rafique, Mubashir Ali Khan*, Shahzad Anjum
}

\begin{abstract}
Social media (SM) usage has gained enormous popularity in recent times which has long lasting effects on people. There is a little research carried out within context of SM and brand relationship quality (BRQ). This study examined the influence of SM on consumer brand relationships among individuals who are active SM and brand users. Total 386 Survey questionnaires were disseminated to the sample population using simple random sampling method, of which 270 questionnaires were properly filled and were analyzed using SPSS program. Further the study revealed that SM is positively related to BRQ and showed significant results in context of our two hypotheses consumer engagement $(\mathrm{p}=0.000)$ and consumer purchase intention $(p=0.000)$, whilst the third hypothesis of the study which is information showed insignificant results $(p=0.168)$. The study contributes to research by recommending that BRQ can be further discussed extensively by using SM, keeping in mind different variables of the study.
\end{abstract}

Keywords: Social Media, Brand Relationship, Trust

*Department of Management Sciences, Bahria University, Karachi 


\section{Introduction}

With the rise in use of social media (SM) the traditional marketing is replaced by two way communication between marketers and consumers. This has increased the control at the end of consumers who dictate the nature, reach and context of marketing messages, along with the extension of effect through shared content ${ }^{1}$. SM being progressively popular is accessed and used everywhere and anytime. Therefore, marketers are adopting some strategies to reach consumers who use SM extensively, while emphasizing on competing for consumer's SM attentiveness to drive customer engagement. SM provides a platform to the marketers where they can engage in two way communication with their existing as well as potential customers, at the same time providing deeper insights of consumer preferences and intentions quicker than ever. The increasing value and usage of SM, brand referrals and information sharing is also considered by the marketers nowadays. SM serves as an emerging and dominating digital communication system which has provided consumers to learn, share ideas and information, and interconnect with the brands they intend to purchase ${ }^{2}$.

According to a study ${ }^{3}$, the rate of internet penetration is $96 \%$ approx. of world population for both men and women. $88 \%$ of adults in US alone use some form of SM, although majority of them use most popular SM sites such as YouTube (73\%), Facebook (68\%), Instagram (35\%), Pinterest (29\%), Snapchat (27\%), LinkedIn (25\%), Twitter (24\%) and WhatsApp (22\%) Pakistan ranks $25^{\text {th }}$ largest country in context of number of internet users in 2016.

In one of the survey of Facebook (FB), it was revealed that average FB consumer has 130 contacts, and when individuals hear about any manufactured article or service from a friend, they are more likely to consume that product or service at a rate of $15 \%$ greater than they find about the same product or service by other sources ${ }^{5}$. Moreover, it has been observed that people who interact through SM engage in some activities that provide information about certain products and services. The current

\footnotetext{
Hanna, Rohm, and Crittenden, 'We're All Connected'.

2 Chappuis, Gaffey, and Parvizi, 'Are Your Customers Becoming Digital Junkies?'; Qualman, Socialnomics.

3 ICT, 'ICT Facts and Figures 2017'.

4 Smith, Monica, and erson, 'Social Media Use in 2018'.

5 ComScore, '- ComScore, Inc'.
} 
generation of consumers, defined in one of the reports of comScore aged 1834 years old is known to exhibit far different digital behaviors than general population. Considering that this group spends $86 \mathrm{hrs}$. /month on SM and mobile apps 23 more hours than older counterparts, it is worth exploring the usage of SM for brand relationships.

SM has turn into an effective tool for businesses for creating and gaining a competitive advantage over competitors. Online sources for marketing and advertising a particular product or service is comparatively cheaper, and is easy to reach and attract potential buyers. Consumers who use SM create relationships with brands and it has gained much attention in marketing theory and practice. People on SM are much inclined towards getting information, engaging with particular brands, and intending to buy products and services offered. This has become progressive with excessive use of digital media, and companies are finding effective ways to create consumer relationships. Since Brands have been an exemplary tool for viable relationships, consumers today have an easy access to engage in dialogue and continue an exchange with brands. The contemporary marketplace with greater interaction and digitalization has enabled consumers to create close brand relationships, which are considered to be widely desired brand associations, and has facilitated companies to achieve competitive advantage. The attention and involvement of consumers through SM is now diverted by many brands all around the world ${ }^{6}$. It is because of the fact that companies are more focusing on marketing their brands on SM in order to seek improved interaction with existing and potential customers to increase profits. Moreover, in a study ${ }^{7}$, it was propounded that SM is used in many ways for branding. Generally, social networking sites are mostly used by different brands for creating relationships with their fans. Consequently, these relationships prove to be generating positive emotions with users.

Most of the social networking sites are used by different bands to develop relationships with their fans. These in turn can generate positive emotions and connections with potential users. Individuals who are indulged in using SM are likely to have extraordinary experiences related to brands, whilst

\footnotetext{
Graves, 'What Can Social Media Intelligence Do for Your Brand'.

Celaya, 'The Company in Web 2.0: The Impact of Social Networks and New Forms of Online Communication in Business Strategy Without a Collection: Amazon.Es: Javier Celaya: Books'.
} 
creating greater affiliations with brands ${ }^{8}$. It is observed that SM has become controlling tower for brand communication ${ }^{9}$. Also, it can be said that consumer behaviors such as their engagement with brand and purchase intensions can be influenced by SM interactions. For building relationships involvement is considered as an important aspect. Involvement investigation regarding relationship building has academically moved to interactive customer/brand relationship with rise of SM platform ${ }^{10}$.

However, there has been seen proliferated work in this field of study, but it is rarely discussed according to Pakistani market and particularly in reference to $S M$ and $B R Q$. Recently, the interest has been increased in understanding $B R Q$ with respect to $\mathrm{SM}$, and there is lesser evidence about what elements encourage individuals to build strong relationships with brands when they use SM.

This study addresses and explores the influence of SM interactions, particularly through information sharing, consumer engagement, and consumer purchase intentions on $B R Q$. More precisely, we required to answer the following questions about SM and customer-brand relationships:

Q: How does a consumer builds relationship with a particular brand through social media interaction?

Q: Do Social Media promote brand relationship quality through consumer engagement?

Q: Do Social Media promote Consumer Purchase intentions for brands?

\section{LITERATURE REVIEW}

From previous studies, it is obvious that SM has gained significance as a traditional media channel in society. The rise in usage of SM has such an intense effect on society that it can be seen not just technological revolution but as well as cultural one. SM is defined as "activities, practices, and behaviors among individuals who meet online for sharing information, ideas, and awareness ${ }^{11}$. These are the tools used for communicating having Web 2.0

8 Trusov, Bodapati, and Bucklin, 'Determining Influential Users in Internet Social Networks'; Yang, 'The Decision Behavior of Facebook Users'.

9 Arrigo, 'Social Media Marketing in Luxury Brands'.

10 Bowden, 'The Process of Customer Engagement'; Hennig-Thurau et al., 'The Impact of New Media on Customer Relationships'.

11 Safko and Brake, The Social Media Bible. 
characteristics, meaning that they are "participatory, collaborative, have knowledge sharing and user friendly tools available on the Web". In one of the study conducted by info-graphics it was observed that people using Facebook and Twitter are more inclined towards talking, recommending, and purchasing company products when they are engaged with that company through SM ${ }^{12}$. Moreover, SM provides a platform for consumers where they can share information about products, services, and brands ${ }^{13}$.

Brand relevance in SM is an extent to which the brand is perceived to expand SM sphere. This implies that brand relevance from consumer point of view is seemed to be the relevance of brand to exist in SM and the degree to which the brand is relevant in the way it stimulates $\mathrm{SM}^{14}$. Furthermore, SM has been seen important for branding, acquisition, and retention, because it helps to build strong brand image. Further, SM interaction promotes to manage and endorse brand presence. It was examined in a study that customers are more likely to be involved with product or service through SM, as it promotes direct conversations between brands and customers, which lead to develop brand loyalty towards those brands that are frequently discussed over SM ${ }^{15}$. SM has enabled customer engagement and can also be linked with customer purchase intentions. It provides companies to interact with customers who are willing to purchase their products when they come to know about them on SM. In this way, through SM can serve and respond to customer needs in better ways ${ }^{16}$. As investigated in one of the researches ${ }^{17}$, customer engagement through SM communities can lead to brand development and brand loyalty. As consumers are contacting brands through SM all around the world, it is likely that consumer choice about particular brand is established when purchase decision is made.

One of the key constructs in marketing is consumer purchase intention which has been used in different contexts including multiple variables such as "consumer attitudes"18, "perceived value"19, "perceived risk", "usefulness",

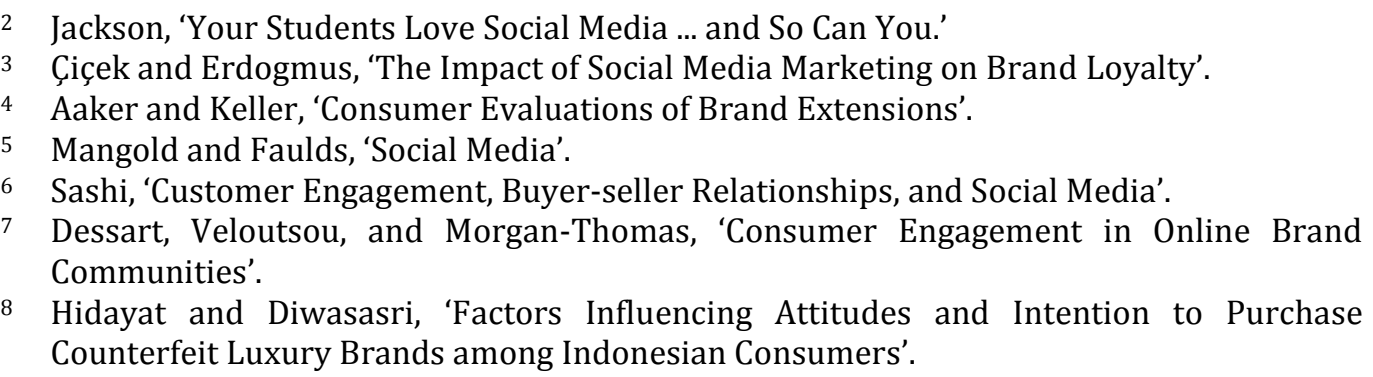


and "ease of use" 20 . In background of SM many studies have been undertaken with regard to purchase intention, showing that individuals decide purchasing on the basis of product characteristics, services, and brands ${ }^{21}$. Growing SM websites like Facebook, Twitter, and YouTube have enabled the users to share and spread information and contents about a related product or brand that they use. Consequently, before making any purchase decision about any product, consumers are becoming more informative and concerned about getting information about product features ${ }^{22}$.

It has nowadays become important to understand consumer brand interactions in order to create relationships ${ }^{23}$. Consumers are mostly inclined to develop relationships with those brands which they consider valuable for themselves and their personalities to create a self-image or self-concept ${ }^{24}$. Thus, consumer brand relationships are regarded as reflection of consumer self ${ }^{25}$. Since, people use to interact with each other either on the basis of functional or emotional attachments, these relationships portray a significant impact on them as well personally and functionally. In similar fashion, it is considered that interacting with a particular brand can also foster relationships with the same brand ${ }^{26}$. Supporting this argument it was found that "consumers are emotionally attached to brands" 27. Additionally, marketing strategies are said to be behavior of a brand, therefore, consumers are more prone to develop relationships with brands keeping in mind their characteristics. Apparently, brands are considered as an active partner of individuals rather, a mere passive object, which in turn very difficult to replace because of the consumer attachment with that particular brand.

$B R Q$ has been theorized differently by different researchers frequently. It is regarded as a multi-faceted construct including relationship constituents and

19 Shaharudin et al., 'Purchase Intention of Organic Food in Malaysia; A Religious Overview'.

20 Fagih, 'Exploring the Influence of Perceived Risk and Internet Self-Efficacy on Consumer Online Shopping Intentions'.

21 Husnain and Toor, 'The Impact of Social Network Marketing on Consumer Purchase Intention in Pakistan'.

22 Saleh, 'Social Networks and Customer Relationship Development at the Saudi Telecommunication Service Providers'.

23 Swaminathan, Page, and Gürhan-Canli, "'My" Brand or "Our” Brand'.

24 Klipfel, Barclay, and Bockorny, 'Self-Congruity'.

25 Escalas and Bettman, 'Self-Construal, Reference Groups, and Brand Meaning'.

26 Fayrene and Lee, 'Customer-Based Brand Equity'.

27 Fournier, 'Consumers and Their Brands', 1998. 
socio-motive attachments. In a study brand relationship strength, stability, and consistency were measured by using different constructs, consisting of these elements: "commitment, interdependence, love and passion, intimacy, self-connection, and brand partner quality" ${ }^{28}$. In literature $B R Q$ is defined as a "consumer-based" measure that shows strength and depth of relationship between consumer and brand", and this concept has significantly attracted interest from academic point of view ${ }^{29}$. It was observed that what people possess is an important part of their personalities ${ }^{30}$. More expressively, consumers relate their personalities with brands while representing them. Customers who project themselves on brands show strong connection with the same brand ${ }^{31}$. It has been noted that most cited work for $B R Q$ is theorizing the BRQ concept. The constructs of BRQ produce a wide spectrum of factors contributing towards establishment of stable and long lasting consumer brand relationships, which are "affective grounding (love and passion), self-connection (identity expression), trust, interdependence, commitment, intimacy, and partner quality"32.

Brand relationship is considered as an idea which connects customers and bands with one another ${ }^{33}$. Marketers therefore, focus on maintaining this relationship by adopting some strategies. Previous studies have focused on long term relationships with consumers, thus, relationship aspect with regard to building quality cannot be overlooked ${ }^{34}$. Consumer adaptation and differentiation of brands forced researchers to focus on brand attitudes and perceived quality ${ }^{35}$. There are several empirical studies supporting the role of $B R Q$ in increased purchase intentions, unwillingness to switching brand, inclination towards sharing personal information with the company, and word of mouth behaviors ${ }^{36}$.

Fournier, 'Consumers and Their Brands', 1998.

29 Smit, Bronner, and Tolboom, 'Brand Relationship Quality and Its Value for Personal Contact'.

30 Kleine, 'How Is a Possession\&quot; Me\&quot; Or\&quot; Not Me\&quot;?'; Russell, "„Possessions as the Extended Self “'.

31 Phau and Lau, 'Brand Personality and Consumer Self-Expression'.

32 Fournier, 'Consumers and Their Brands', 1998.

33 McAlexander, Schouten, and Koenig, 'Building Brand Community'.

34 Sheth and Parvatiyar, 'The Evolution of Relationship Marketing'.

35 Campbell and Lane Keller, 'Brand Familiarity and Advertising Repetition Effects'.

36 Harrison-Walker, 'The Measurement of Word-of-Mouth Communication and an Investigation of Service Quality and Customer Commitment As Potential Antecedents'; Huber et al., 'Brand Misconduct'; Smit, Bronner, and Tolboom, 'Brand Relationship Quality and Its Value for Personal Contact'. 
Furthermore, according to research findings of some studies, it was revealed that individuals develop comparatively stronger ties to those social networks which they find similar to their personalities. It is also noted that, people are likely to have future intentions to continue using the same network in light of online network brand, whilst they recommend this to others, also strengthening preferences for other brands utilizing this network for marketing purposes ${ }^{37}$. Conclusively, with an extraordinary advancement in technological innovations, $B R Q$ within context of SM appears to be interesting particularly in testing predictions of $B R Q$.

It has been seen that internet and SM users in Pakistan are increasing day by day, but regardless of its growing dependence on SM usage, very few or little research has been carried out in this particular area.

One of the few studies conducted in Pakistani context was impact of SM on purchasing behavior of Pakistani women. In a study ${ }^{38}$, it was revealed that traditional word of mouth form of advertising is much popular among Pakistani women as compared to SM advertising. However, the study provided some insights about use of SM in Pakistan, the results of the study cannot be generalized it focused on women and garment industry only. Moreover it was found that SM impacts on self-esteem of students of Institute of Business Management who used Facebook. The results of the study show that SM negatively impacts self-esteem of the students ${ }^{39}$.

Moreover, according to a study ${ }^{40}$ the decision making was influenced by using SM. The study was conducted in higher educational institutes of Pakistan which revealed that the SM users made decisions about purchases which are criticized by other users. This implies that SM usage carries negative outcomes as well. While investigating the adoption of SM among distance learners of AIOU, it was examined that although being familiar with SM technologies, people are likely to use Facebook more frequently ${ }^{41}$. The study showed that "perceived usefulness, perceived behavior, and attitude"

37 Pentina et al., 'Drivers and Outcomes of Brand Relationship Quality in the Context of Online Social Networks'.

38 Nasir, Vel, and Mateen, 'Social Media and Buying Behaviour of Women in Pakistan towards the Purchase of Textile Garments'.

39 Jan, Anwar Soomro, and Ahmad, 'Impact of Social Media on Self-Esteem'.

40 Ahmad, Salman, and Ashiq, 'The Impact of Social Media on Fashion Industry'.

41 Kanwal, 'Adoption of Social Media Technologies and Their Impact on Students' Academic Performance'. 
are the factors that can have influence on SM users. Since these studies focus on different aspects of SM usage in Pakistan, the findings may not be able to illustrate to what extent SM can affect the $B R Q$ in Pakistan. Thus, the current study aims to fill in this literature gap.

After reviewing the literature following hypothesis were developed.

H1: Information gained through social media about brand is positively related to Brand relationship quality.

H2: Consumer engagement with brand through social media is positively related to brand relationship quality.

H3: Consumer purchase intention for buying a particular brand through social media is positively related to brand relationship quality.

\section{Research Model:}

Following is proposed research model for the study.

INDEPENDENT VARIABLE (SOCIAL MEDIA)

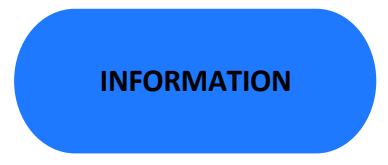

CONSUMER ENGAGEMENT
DEPENDENT VARIABLE

H1

H2

H3
BRAND RELATIONSHIP QUALITY (BRQ)

\section{PURCHASE CONSUMER} INTENTION 


\section{Research Methodology Research Design}

This study is based on quantitative causal research design, in which the researcher is interested to examine the relationship of SM interactions with $B R Q$. The primary data of the study is acquired through administering adopted questionnaire and distributed among the active users of SM in Pakistan.

\section{Data Type}

Cross sectional data was used in this study, as cross sectional study is use to prove and/or disprove the assumptions. One more reason to use this data type is that it's not costly to perform and does not require a lot of time.

\section{Sampling Method}

Simple random sampling was used for this study as Random sampling eliminates biasness by giving all individuals an equal chance to be chosen.

\section{Population and Sample Size}

The target population for this research is Brand consumers from the age of 18 to onwards who are the active users of SM are. The size of the population is 32 million active users of SM overall Pakistan (Information and Communication Technologies for Development (ICTD) 2017). Of which a proportion is taken for SM users in Karachi. The goal is to make the sample as large and representative as possible. The target sample size is defined as 386 (Uma Sekaran) based on a 95\% confidence level and 5\% margin of error.

\section{Survey Instrument}

The self-administered structured questionnaire on five point Likert Scale (adopted from Simon et al 2015 and Areeba et al 2017) is chosen for the data collection purpose.

\section{Data Analysis}

For data analysis purpose the SPSS program was used. 


\section{Results and Discussions}

Table.1 RELIABILITY

\begin{tabular}{|c|c|c|}
\hline Variable & No: of Items & Cronbach's Alpha \\
\hline Information & 4 & .765 \\
\hline Consumer engagement & 5 & .776 \\
\hline Consumer purchase intention & 5 & .817 \\
\hline Brand Relationship Quality & 30 & .974 \\
\hline
\end{tabular}

In the above table reliability statistics shows Cronbach's Alpha of each variable which is greater than .75 that means the internal consistency of the items of the questionnaire is highly acceptable.

Table.2: Gender

\begin{tabular}{|ll|c|c|c|c|}
\hline & Frequency & Percent & Valid percent & $\begin{array}{c}\text { Cumulative } \\
\text { percent }\end{array}$ \\
\hline Valid & Male & 150 & 55.6 & 55.6 & 55.6 \\
& Female & 120 & 44.4 & 44.4 & 100.0 \\
& Total & 270 & 100.0 & 100.0 & \\
\hline
\end{tabular}

The above represents gender category of respondents. The male participants $(\mathrm{n}=150)$ dominated the study results representing $55.6 \%$ of sample, while females $(n=120)$ represented $44.4 \%$ of the sample.

Table.3 Model Summary

\begin{tabular}{|l|c|c|c|c|}
\hline Model & $\mathrm{R}$ & R Squared & Adj. R Square & $\begin{array}{l}\text { Standard error of the } \\
\text { estimate }\end{array}$ \\
\hline 1 & $.658^{\mathrm{a}}$ & .433 & .427 & .75223 \\
\hline
\end{tabular}

Table 3 shows the multiple linear regression model summary and overall fitness statistics. In above table $\mathrm{R}$ denotes the correlation between the predicted variables and the dependent variable BRQ. In this study $\mathrm{R}=.658$. Since this is a good correlation, the model predicts BRQ rather precisely. And the $\mathrm{R}$ square is simply the square of the $\mathrm{R}$, which indicates the proportion of 
variance in the BRQ that can be explained by three predictors of the study (Information, Consumer Engagement, and Consumer purchase intention). The adjusted $\mathrm{R}$ squared of the model is $42.7 \%$.This means that the model explains $42.7 \%$ of variation in the data which means BRQ is explained by $42.7 \%$ through these independent variables i.e. Information, consumer engagement and consumer purchase intention. The remaining $57.3 \%$ is explained by other variables which are not included in the study.

Table.4

ANOVA

\begin{tabular}{|ll|l|c|c|c|c|}
\hline & Model & $\begin{array}{l}\text { Sum of } \\
\text { squares }\end{array}$ & Df & $\begin{array}{c}\text { Mean } \\
\text { square }\end{array}$ & F & Sig. \\
\hline 1 & $\begin{array}{l}\text { Regressio } \\
\text { n }\end{array}$ & 115.154 & 3 & 38.385 & 67.836 & $.000^{\mathrm{b}}$ \\
& $\begin{array}{l}\text { Residual } \\
\text { Total }\end{array}$ & 150.516 & 266 & .566 & & \\
& 265.670 & 269 & & & \\
\hline
\end{tabular}

a. Dependent variable: BRQ_M

b. Predictors (Constant) CONPLNT_M, INFO_M, CONENG_M

The results of ANOVA show that there is statistically significant difference between group means. The $\mathrm{F}$ value for the data set is 67.836. As it can be seen that the significance value is 0.00 (i.e., $p=0.00$ ), which is below 0.05 ., indicating that the outcome variable is predicted significantly by regression model in general (i.e., it is a good fit for the data).

\section{Regression Analysis}

Table.5

\begin{tabular}{|c|c|c|c|c|c|c|c|}
\hline \multirow[b]{2}{*}{ Table } & \multicolumn{2}{|c|}{$\begin{array}{l}\text { Unstandardized } \\
\text { coefficients }\end{array}$} & \multirow{2}{*}{$\begin{array}{l}\text { Standard } \\
\text { coefficient } \\
\text { s } \\
\text { Beta }\end{array}$} & \multirow[b]{2}{*}{$\mathrm{t}$} & \multirow[b]{2}{*}{ Sig. } & \multicolumn{2}{|c|}{ Collinearity statistics } \\
\hline & $\mathrm{B}$ & Std. error & & & & Tolerance & VIF \\
\hline Constant & .859 & .155 & & 5.557 & .000 & & \\
\hline $\begin{array}{l}\text { INFORMATIO } \\
\mathrm{N}\end{array}$ & .090 & .065 & .088 & 1.383 & .168 & .530 & 1.888 \\
\hline CONSUMER & & & & & & & \\
\hline ENGAGEMEN & .281 & .070 & .267 & 3.991 & .000 & .477 & 2.097 \\
\hline $\mathrm{T}$ & & & & & & & \\
\hline CONSUMER & & & & & & & \\
\hline $\begin{array}{l}\text { PURCHASE } \\
\text { INTENTION }\end{array}$ & .410 & .067 & .388 & 6.143 & .000 & .533 & 1.876 \\
\hline
\end{tabular}

a. Dependent Variable: BRQ_M 


\section{Regression Equation:}

$\mathrm{Y}=\beta \mathrm{o}+\beta 1 \mathrm{X} 1+\beta 2 \mathrm{X} 2+\beta 3 \mathrm{X} 3$

$\mathrm{BRQ}=.859+.090$ Info +.281 Consumer Engagement +.410 Consumer

Purchase Intention

Where,

$\mathrm{Y}=$ Brand relationship Quality

$\beta o=$ Constant

$\beta 1=$ Information gained from social media

$\beta 2=$ Consumer Engagement

$\beta 3=$ Consumer Purchase Intention

\section{Information gained from the SM and $B R Q$}

In the table the beta value shows the positive sign 0.090. That means there is a positive impact of information on the BRQ. Since $P$ value is (.168) which is greater than significance value (0.05), that means Ho is failed to reject.

\section{Consumer Engagement and $B R Q$}

In the table the beta value shows the positive sign 0.281 that means there is a positive impact of consumer engagement on SM with BRQ. Since the P value is (.000) which is less than significance value (0.05), that means Ho is rejected.

\section{Consumer Purchase Intention and BRQ}

In the table the beta value shows the positive sign 0.388 that means there is a positive impact on the consumer purchase intention and BRQ. Since the $P$ Value is (0.000) which is less than significance value (0.05), that means Ho is rejected.

\section{Correlation}

TABLE: 06

\begin{tabular}{|c|c|c|c|c|c|}
\hline & & $\begin{array}{c}\text { Informati } \\
\text { on }\end{array}$ & $\begin{array}{c}\text { Consumer } \\
\text { Engageme } \\
\text { nt } \\
\end{array}$ & $\begin{array}{l}\text { Consumer } \\
\text { Purchase } \\
\text { Intention } \\
\end{array}$ & BRQ_M \\
\hline $\begin{array}{l}\text { Informatio } \\
\mathrm{n}\end{array}$ & $\begin{array}{l}\text { Pearson } \\
\text { Correlation } \\
\text { Sig. (2-tailed) }\end{array}$ & 1 & $\begin{array}{l}.647^{* *} \\
.000\end{array}$ & $\begin{array}{l}.591^{* *} \\
.000\end{array}$ & $\begin{array}{l}.490^{* *} \\
.000\end{array}$ \\
\hline
\end{tabular}




\begin{tabular}{|ll|c|c|c|c|}
\hline & $\mathrm{N}$ & 270 & 270 & 270 & 270 \\
\hline Consumer & Pearson & $.647^{* *}$ & 1 & $.644^{* *}$ & $.573^{* *}$ \\
Engageme & Correlation & .000 & & .000 & .000 \\
nt & Sig. (2-tailed) & .000 & & 270 \\
& $\mathrm{~N}$ & 270 & 270 & 270 & $.612^{* *}$ \\
\hline Consumer & Pearson & $.591^{* *}$ & $.644^{* *}$ & 1 & .000 \\
Purchase & Correlation & .000 & .000 & & 270 \\
Intention & Sig. (2-tailed) & 270 & 270 & 270 & 1 \\
& $\mathrm{~N}$ & $.490^{* *}$ & $.573^{* *}$ & $.612^{* *}$ & \\
\hline BRQ_M & Pearson & .000 & .000 & .000 & \\
& Correlation & 270 & 270 & 270 \\
& Sig. (2-tailed) & .000 & 270 & & \\
& $\mathrm{~N}$ & 270 &
\end{tabular}

**. Correlation is significant at the 0.01 level (2-tailed).

The above table shows correlations for the variables used in the study, one dependent variable $B R Q$ is included along with three independent variables of SM (information, consumer engagement, and consumer purchase intention). The positive relationship was found between dependent and independent variables. The relationship shows significance and is positive at $(\mathrm{r}=$.490) for BRQ and information, also for consumer engagement and consumer purchase intention the relationship is positive and significant at $(\mathrm{r}=.573$ and $\mathrm{r}=.612)$ respectively.

This study was done in order to increase our understanding on $B R Q$ with relation to SM, by taking into account information, consumer engagement, and consumer purchase intention. $B R Q$ has been greatly discussed in previous studies, and within context of SM there is a much need to conduct more studies. Moreover the study reveals alignment of the results with previous literature and support the relationship of SM with BRQ.

\section{Conclusion}

With rapidly changing technologies and advancements in digital media, Pakistan has also been among those countries that are experiencing an increasing rise is SM usage in last few years. Because of this reason it concentrates on the fact that further studies should be conducted in Pakistani context. It was revealed in the findings that Pakistani internet users are more inclined towards SM engagement through different platforms and brands. 
Furthermore, the study presented that SM can be used as a base to successfully create $B R Q$. More precisely it can be concluded that SM has distinctive features for consumers who use to engage on different platforms of SM. In addition, it can provide consumers with more opportunities for sharing personal experiences and other related information of brands, products, and services.

The results of the study imply that in Pakistan it is much needed to consider the role of SM in order to create $B R Q$ with respect to information gained through SM, consumer engagement, and consumer purchase intention.

\section{Limitations and Future Research Directions}

The very common limitation of the study is time constraints and limited participants. It was not possible to conduct the huge survey in this time limit so the results are not up to the researcher's expectations. Besides the study has validated the impact of SM interactions on $B R Q$, but it still has some limitations. There are other factors which can influence $B R Q$ for further understanding of the concept, so they can be included in further studies. Moreover, it is recommended to conduct studies on the basis of comparison of SM users on the basis of gender and age factor in particular. 


\section{References}

Aaker, David A., and Kevin Lane Keller. 'Consumer Evaluations of Brand Extensions'. Journal of Marketing 54, no. 1 (January 1990): 27. https://doi.org/10.2307/1252171.

Ahmad, Nawaz, Atif Salman, and Rubab Ashiq. 'The Impact of Social Media on Fashion Industry: Empirical Investigation from Karachiites'. Journal of Resources Development and Management 7 (30 April 2015): 1-7.

Arrigo, Elisa. 'Social Media Marketing in Luxury Brands: A Systematic Literature Review and Implications for Management Research'. Management Research Review, 3 April 2018. https://doi.org/10.1108/MRR-04-2017-0134.

Bowden, Jana Lay-Hwa. 'The Process of Customer Engagement: A Conceptual Framework'. Journal of Marketing Theory and Practice 17, no. 1 (1 January 2009): 63-74. https://doi.org/10.2753/MTP1069-6679170105.

Campbell, Margaret, and Kevin Lane Keller. 'Brand Familiarity and Advertising Repetition Effects'. Journal of Consumer Research 30 (1 February 2003): 292-304. https://doi.org/10.1086/376800.

Celaya, Javier. 'The Company in Web 2.0: The Impact of Social Networks and New Forms of Online Communication in Business Strategy Without a Collection: Amazon.Es: Javier Celaya: Books', November 2011. https://www.amazon.es/empresa-web-2-0-comunicaci\%C3\%B3nempresarial/dp/849875173X.

Chappuis, Bertil, Brendan Gaffey, and Parviz Parvizi. 'Are Your Customers Becoming Digital Junkies?', 2011.

Çiçek, Mesut, and Irem Erdogmus. 'The Impact of Social Media Marketing on Brand Loyalty'. Procedia - Social and Behavioral Sciences 58 (1 October 2012): 1353-60. https://doi.org/10.1016/j.sbspro.2012.09.1119.

ComScore. '- ComScore, Inc'. comScore, Inc., 2011. http://www.comsc ore.com/Press_Events/Presentations_Whitepapers/2011/2010_Mobile_Year _in_Review). 
Dessart, Laurence, Cleopatra Veloutsou, and Anna Morgan-Thomas. 'Consumer Engagement in Online Brand Communities: A Social Media Perspective'. Journal of Product \& Brand Management 24, no. 1 (16 March 2015): 28-42. https://doi.org/10.1108/JPBM-06-2014-0635.

Escalas, Jennifer Edson, and James R. Bettman. 'Self-Construal, Reference Groups, and Brand Meaning'. Journal of Consumer Research 32, no. 3 (2005): 378-389.

Fagih, Khaled. 'Exploring the Influence of Perceived Risk and Internet SelfEfficacy on Consumer Online Shopping Intentions: Perspective of Technology Acceptance Model' 9 (1 January 2013).

Fayrene, Chieng YL, and Goi Chai Lee. 'Customer-Based Brand Equity: A Literature Review'. Researchers World 2, no. 1 (2011): 33.

Fournier, Susan. 'Consumers and Their Brands: Developing Relationship Theory in Consumer Research'. Journal of Consumer Research 24, no. 4 (1998): 343-373.

- - - 'Consumers and Their Brands: Developing Relationship Theory in Consumer Research'. Journal of Consumer Research 24, no. 4 (1998): 343373.

- - - 'Consumers and Their Brands: Developing Relationship Theory in Consumer Research'. Journal of Consumer Research 24, no. 4 (1998): 343373.

Graves, Justin. 'What Can Social Media Intelligence Do for Your Brand', 2016. https://www.ama.org/resources/Best-Practices/Pages/What-Can-SocialMedia-Intelligence-Do-for-Your-Brand.aspx.

Hanna, Richard, Andrew Rohm, and Victoria L. Crittenden. 'We're All Connected: The Power of the Social Media Ecosystem'. Business Horizons 54, no. 3 (May 2011): 265-73. https://doi.org/10.1016/j.bushor.2011.01.007.

Harrison-Walker, L. Jean. 'The Measurement of Word-of-Mouth Communication and an Investigation of Service Quality and Customer Commitment As Potential Antecedents'. Journal of Service Research 4, no. 1 (1 August 2001): 60-75. https://doi.org/10.1177/109467050141006. 
Hennig-Thurau, Thorsten, Edward C. Malthouse, Christian Friege, Sonja Gensler, Lara Lobschat, Arvind Rangaswamy, and Bernd Skiera. 'The Impact of New Media on Customer Relationships'. Journal of Service Research 13, no. 3 (1 August 2010): 311-30. https://doi.org/10.1177/1094670510375460.

Hidayat, Anas, and Ayu Hema Ajeng Diwasasri. 'Factors Influencing Attitudes and Intention to Purchase Counterfeit Luxury Brands among Indonesian Consumers'. International Journal of Marketing Studies 5, no. 4 (16 July 2013). https://doi.org/10.5539/ijms.v5n4p143.

Huber, Frank, Kai Vollhardt, Isabel Matthes, and Johannes Vogel. 'Brand Misconduct: Consequences on Consumer-Brand Relationships'. Journal of Business Research 63, no. 11 (2010): 1113-20.

Husnain, Mudassir, and Areeba Toor. 'The Impact of Social Network Marketing on Consumer Purchase Intention in Pakistan: Consumer Engagement as a Mediator'. Asian Journal of Business and Accounting 10, no. 1 (2017): 167-199.

ICT. 'ICT Facts and Figures 2017', 2017. https://www.itu.int/en/ITUD/Statistics/Pages/facts/default.aspx.

Jackson, Camille. 'Your Students Love Social Media ... and So Can You.' Teaching Tolerance, 2011. http://scihub.tw/https://eric.ed.gov/?id=EJ930783.

Jan, Muqaddas, Sanobia Anwar Soomro, and Nawaz Ahmad. 'Impact of Social Media on Self-Esteem'. European Scientific Journal 13 (31 August 2017): 32941. https://doi.org/10.19044/esj.2017.v13n23p329.

Kanwal, Saima. 'Adoption of Social Media Technologies and Their Impact on Students' Academic Performance: The Only Way for Future Survival of Distance Education Students in Pakistan' 18 (1 January 2016).

Kleine, Susan. 'How Is a Possession\&quot; Me\&quot; Or\&quot; Not Me\&quot;? Characterizing Types and an Antecedent of Material Possession Attachment'. The Journal of Consumer Research 22 (1995). 
https://www.academia.edu/635486/How_is_a_possession_me_or_not_me_C haracterizing_types_and_an_antecedent_of_material_possession_attachment.

Klipfel, Joseph AL, Allen C. Barclay, and Kristi M. Bockorny. 'Self-Congruity: A Determinant of Brand Personality'. Journal of Marketing Development and Competitiveness 8, no. 3 (2014): 130.

Mangold, W. Glynn, and David J. Faulds. 'Social Media: The New Hybrid Element of the Promotion Mix'. Business Horizons 52, no. 4 (July 2009): 35765. https://doi.org/10.1016/j.bushor.2009.03.002.

McAlexander, James H., John W. Schouten, and Harold F. Koenig. 'Building Brand Community'. Journal of Marketing 66, no. 1 (January 2002): 38-54. https://doi.org/10.1509/jmkg.66.1.38.18451.

Nasir, Saadia, Prakash Vel, and Hafsa Mateen. 'Social Media and Buying Behaviour of Women in Pakistan towards the Purchase of Textile Garments'. University of Wollongong in Dubai - Papers, 1 January 2012, 61-69.

Pentina, Iryna, Bashar S. Gammoh, Lixuan Zhang, and Michael Mallin. 'Drivers and Outcomes of Brand Relationship Quality in the Context of Online Social Networks'. International Journal of Electronic Commerce 17, no. 3 (1 April 2013): 63-86. https://doi.org/10.2753/JEC1086-4415170303.

Phau, I., and K. C. Lau. 'Brand Personality and Consumer Self-Expression: Single or Dual Carriageway?' Journal of Brand Management 8, no. 6 (1 July 2001): 428-44. https://doi.org/10.1057/palgrave.bm.2540042.

Qualman, Erik. Socialnomics: How Social Media Transforms the Way We Live and Do Business. Hoboken, N.J: Wiley, 2009.

Russell, Belk. '„Possessions as the Extended Self “'. Journal of Consumer Research 2 (1988).

Safko, Lon, and David K. Brake. The Social Media Bible: Tactics, Tools, and Strategies for Business Success. John Wiley \& Sons, 2009.

Saleh, Mahmoud Abdel Hamid. 'Social Networks and Customer Relationship Development at the Saudi Telecommunication Service Providers'. 
International Journal of Marketing Studies 8, no. 4 (27 July 2016): 77. https://doi.org/10.5539/ijms.v8n4p77.

Sashi, C.M. 'Customer Engagement, Buyer-seller Relationships, and Social Media'. Management Decision 50, no. 2 (2 March 2012): 253-72. https://doi.org/10.1108/00251741211203551.

Shaharudin, Mohd Rizaimy, Jacqueline Junika Pani, Suhardi Wan Mansor, Shamsul Jamel Elias, and Daing Maruak Sadek. 'Purchase Intention of Organic Food in Malaysia; A Religious Overview'. International Journal of Marketing Studies 2, no. 1 (19 April 2010): 96. https://doi.org/10.5539/ijms.v2n1p96.

Sheth, Jagdish N., and Atul Parvatiyar. 'The Evolution of Relationship Marketing'. International Business Review 4, no. 4 (1995): 397-418.

Smit, Edith, Fred Bronner, and Maarten Tolboom. 'Brand Relationship Quality and Its Value for Personal Contact'. Journal of Business Research, Consumer Personality and Individual Differences, 60, no. 6 (1 June 2007): 627-33. https://doi.org/10.1016/j.jbusres.2006.06.012.

Smith, Aaron, Monica, and erson. 'Social Media Use in 2018'. Pew Research Center: Internet, Science \& Tech (blog), 2018. http://www.pewinternet.org/2018/03/01/social-media-use-in-2018/.

Swaminathan, Vanitha, Karen L. Page, and Zeynep Gürhan-Canli. "My" Brand or "Our" Brand: The Effects of Brand Relationship Dimensions and SelfConstrual on Brand Evaluations'. Journal of Consumer Research 34, no. 2 (2007): 248-259.

Trusov, Michael, Anand V Bodapati, and Randolph E Bucklin. 'Determining Influential Users in Internet Social Networks'. Journal of Marketing Research 47, no. 4 (1 August 2010): 643-58. https://doi.org/10.1509/jmkr.47.4.643.

Yang, Taining. 'The Decision Behavior of Facebook Users'. Journal of Computer Information Systems 52, no. 3 (1 March 2012): 50-59. https://doi.org/10.1080/08874417.2012.11645558. 